\title{
TEACHING OF MEDICAL PARASITOLOGY AT BUKOVINIAN STATE MEDICAL UNIVERSITY
}

(Literature review and own research)

\author{
R.Ye. Bulyk, M.I. Kryvchanska, K.V. Vlasova, V.R. Yosypenko, O.V. Smetaniuk
}

HSEE of Ukraine "Bukovinian State Medical University", Chernivtsi

Parasitic infestations account for a significant percentage of overall morbidity and mortality. In this regard, the problem of parasitic pathology often occurs in the practice of physicians, which necessitates an increase in the level of professional training of physicians. It is necessary to expand the knowledge of health professionals not only about the clinical symptoms, diagnosis and treatment of infestations, but also about the epidemiological features and life cycles of parasites that underlie the development of the methods for the prevention of parasitic diseases.

The aim of the work is to analyze the peculiarities of teaching medical parasitology to the first-year students of the Higher State Educational Establishment of Ukraine "Bukovinian State Medical University" in order to improve teaching methods in the training of doctors.

Conclusion. Teaching medical parasitology includes lectures, practical classes, independent work of students, conducting two final modular tests, which include computer testing, theoretical questions, practical skills. The peculiarity of the study of medical parasitology is the use of a large amount of visual material: tables, diagrams, illustrations, photographs, microslides and museum specimens.

\section{ВИКЛАДАННЯ МЕДИЧНОЇ ПАРАЗИТОЛОГІЇ У БУКОВИНСЫКОМУ ДЕРЖАВНОМУ МЕДИЧНОМУ УНІВЕРСИТЕТІ (огляд літератури та власний досвід)}

\section{Р.С. Булик, М.І. Кривчанська, К.В. Власова, В.Р. Йосипенко, О.В. Сметанюк}

Паразитарні інвазї складають вагомий відсотоку загальному рівні захворюваності та смертності. У зв'язку з циим у практичній діяльності лікаря часто траплясться проблема паразитарної патології, щзо зумовлює необхідність підвищення рівня професійної підготовки лікарів. Необхідним є розширення знань медичних працівників не тільки про клінічну симптоматику, діагностику та лікування інвазій, але й про епідеміологічні особливості та життєві цуикли паразитів, які лежать в основі створення методів профілактики паразитозів.

Мета роботи - аналіз особливостей викладаннямедичної паразитології студентам першого курсу Вищого державного навчального закладу України «Буковинський державний медичний університет» з метою удосконалення методів навчання при підготовиі лікарів.

Висновок. Викладання медичної паразитологї̈ передбачає лекиії, практичні заняття, самостійну роботу студентів, проведення двох підсумкових модульних контролів, які включають комп'ютерне тестування, теоретичні питання, практичні навички. Особливістю вивчення медичної паразитологї є використання великої кількості наочного матеріалу: таблиць, схем, ілюстрацій, фотографій, мікропрепаратів та музейних експонатів.

\section{ПРЕПОДАВАНИЕ МЕДИЦИНСКОЙ ПАРАЗИТОЛОГИИ В БУКОВИНСКОМ ГОСУДАРСТВЕННОМ МЕДИЦИНСКОМ УНИВЕРСИТЕТЕ \\ (Обзор литературы и собственные исследования)}

\section{Р.Е. Булык, М.И. Кривчанская, К.В. Власова, В.Р. Йосипенко, А.В. Сметанюк}

Паразитарные инвазии составляют значительный процент в общем уровне заболеваемости и смертности. В связи с этим в практической деятельности врача часто встречается проблема паразитарной патологии, что обусловливает необходимость повышения уровня профессиональной подготовки врачей. Необходимым является расширение знаний медицинских работников не только о клинической симптоматике, диагностике и лечении инвазий, но и об эпидемиологических особенностях и жизненных циклах паразитов, которые лежат в основе создания методов профилактики паразитозов.

Цель работы - анализ особенностей преподавания медицинской паразитологии студентам первого курса Высшего государственного учебного заведения
Key words:

medical biology, medical parasitology, higher school, teaching methods, education.

Clinical and experimental pathology 2020. Vol.19, №3 (73). P.185-190.

DOI:10.24061/1727-4338

XIX.3.73.2020.26

E-mail:

krivmar@bsmu.edu.ua

Ключові слова:

медична біологія, медична паразитологія, вищза школа, методи навчання, освіта.

Клінічна та експериментальна патологія 2020. Т.19, №3(73). C.185-190.

\section{Ключевые слова:} медицинская биология, медицинская паразитология, выстиая школа, методы обучения, образование.

Клиническая и экспериментальная патология 2020. T.19, №3 (73). C.185-190. 
Украины «Буковинский государственный медицинский университет» с изелью усовершенствовать методы обучения при подготовке врачей.

Вывод. Преподавание медицинской паразитологии предусматривает лекции, практические занятия, самостоятельную работу студентов, проведение двух итоговых модульных контролей, которые включают компьютерное тестирование, теоретические вопросы, практические навыки. Особенностью изучения медииинской паразитологии является использование большого количества наглядного материала: таблии, схем, иллюстраций, фотографий, микропрепаратов и музейных экспонатов.

\section{Introduction}

According to WHO, the cause of the annual death of more than 16 million people in the world are infectious and invasive diseases, and a third of the population of Europe is infected with one or more helminthiases. For example, 400-600 thousand new cases of helminthiasis are registered annually in Ukraine, and population migration creates the problem of the emergence of tropical parasites in different regions of Ukraine and the world. Today, more and more cases of malaria are registered in Ukraine, which were brought from abroad, and it is noted that in recent years, mainly tropical malaria is brought, which is characterized by a severe course and high, about $1 \%$, mortality, which is $1-3$ million deaths in the world annually.

According to the latest data, the incidence rate of helminthiasis is 1333 cases per 100,000 population in Ukraine, while the number of patients with nematodes is 5,000,000, almost every 10th citizen of Ukraine is infested with enterobiasis, ascariasis. The incidence rate for tissue helminthiases is also growing, in particular, toxocariasis, echinococcosis and dirofilariasis. The situation is significantly complicated by untimely laboratory diagnostics of helminthiasis and asymptomatic parasitic carriers.

The increase in the number of patients with parasitic infestations among the population prompts us to develop more advanced methods of their diagnosis, treatment and prevention, and also exacerbates the issue of increasing the level of professional training of future doctors.

The aim of the work is to analyze the features of teaching medical parasitology to the first and second year students of Higher State Educational Establishment of Ukraine "Bukovinian State Medical University" in order to improve teaching methods in the training of practical doctors.

\section{Body}

The modernization of the higher education system in Ukraine is characterized by a combination of the traditional domestic school and the latest global trends associated with Ukraine's entry into the European educational space. Analysis of literary sources shows that the introduction of innovative teaching models, modern e-learning technologies, distance learning is becoming necessary in the formation of a modern highly qualified, competitive specialist. The quality of domestic education, educational standards and norms do not always correspond to the needs of existing world norms $[1,2,5,7,8]$.

To improve the quality of training competitive doctors, teachers of the Department of Medical Biology and ISSN 1727-4338 https://www.bsmu.edu.ua
Genetics are constantly updating materials of lectures and methodological recommendations for practical exercises using the latest achievements of medicine and pharmacy. In the preparation of teaching materials, the ability to proper organization and structure of the lesson plays an important role. When studying medical parasitology, an important point is to determine the relevance of the lesson topic, in order to motivate the student properly to perceive and memorize educational material, it is important to emphasize the further use of the information received in practice. In our opinion, it is necessary for this purpose to indicate the percentage of parasitic invasions in the structure of the general morbidity of the population and the widespread occurrence of these nosologies in the world.

Lectures take the leading part in the organization of the educational process, lecturers use an illustrative method of presenting information using multimedia, the presentation of the material is accompanied by various images, tables and diagrams, fragments of videos, demonstration of micro and macro preparations for maximum clarity, which facilitates the perception of the educational material by students.

During practical classes, the teacher focuses the attention of students on the main content and relevance of studying the topic. In our experience, we have determined that when studying medical parasitology, the main teaching methods are: explanatory-illustrative method or information-receptive (lecturing in front of an audience using multimedia presentations, conducting webinars using modern Internet learning technologies); reproductive method (conducting practical classes using electronic textbooks, databases of Internet resources, applying and recording what was learned on the basis of a sample or rule in students' work (protocol) notebooks; reproduction of knowledge during oral questioning of a student; consolidation of knowledge when performing practical work; intermediate and final control of knowledge using computer test control of knowledge); the method of problem presentation (formulation of a problem with a stating of a task based on various sources and means, followed by comparison of points of view, different approaches under the supervision of a teacher, conducting a scientific search on a specific problem); research method (independent study of literature, scientific sources, followed by comparison of points of view, different approaches under the supervision of a teacher, conducting a scientific search on a specific problem, educational research and research work of students (in practical classes, work in the SSW of the department, participation in conferences, academic competitions, etc.); business (role-playing) games (distribution of Клінічна та експериментальна патологія. 2020. Т.19, № 3 (73) 
roles between students (the role of a patient, admission doctor, laboratory assistant, pharmacist), which can be used in the study of parasitic diseases. This will give an opportunity to activate students' thinking; to increase the independence of the future specialist; bring the spirit of creativity into teaching; to bring training closer to the professional activity; prepare the student for professional practical activity); discussion methods (elements of discussion: disputes, clash of positions, deliberate exacerbation and even exaggeration of contradictions in the discussed content) can be used in almost any form of education, including lectures, discussion methods act as a means of not only teaching, but also education); modeling method (this is a method of creating and researching models. A model is an imaginary or materially realized system that adequately reflects the subject of research and is able to replace it in such a way that the study of the model contributes to obtaining new information about this subject) $[3,4,6,9]$.

The use of computer technologies plays an important role in the educational process. The arsenal of multimedia technologies includes animation graphics, videos, sound, interactive capabilities, the use of remote access and external resources. With the help of such methods and an interactive whiteboard, teachers of the department create many interesting projects for students.

The use of these technologies gives a unique opportunity to provide a huge amount of useful and interesting information in the most convenient and accessible form. The use of multimedia in the teaching process increases the effectiveness of the study of medical parasitology of students due to the influence of graphic and verbal stimuli that contribute to the construction of visual and auditory types of perception in them.

The department pays great attention to the acquisition of practical skills. When studying medical parasitology, students demonstrate the ability to distinguish the most common human parasites by morphological characteristics in laboratory studies, for which the department uses photographs, micro- and macropreparations of human parasites from the sections "Medical protozoology", "Medical helminthology" and "Medical arachnoentomology". It is important not only to diagnose parasitic pathology, but also to prevent it in a timely manner, therefore, at the department teachers instruct students to use the knowledge of parasite life cycles to justify preventive measures.

During the study of the discipline, a systematic survey and assessment of all students of the academic group is necessary. The use of test items makes it possible to determine the level of assimilation of the material by the students and to identify gaps in knowledge on the topic. Test control allows the teacher to test the knowledge of all students of the academic group at the same time and form their need for preparation for each practical lesson.

The teachers of the department pay special attention to the test tasks for the preparation of the Unified State Examination (unified state qualification exam for applicants for a master's degree in higher education in the specialties of the branch of knowledge "22 Healthcare"), Stage 1 Integrated test exam "KROK1" and the exam in English, which is passed after learning fundamental Клінічна та експериментальна патологія. 2020. Т.19, № 3 (73) disciplines. In practical classes, teachers analyze test tasks on the topic of the lesson that were offered to the students of the past years (in Ukrainian and English), commenting and focusing on the main key concepts. This type of work demonstrates a good result in the final modular control and the exam "KROK1" itself.

When studying the section "Medical parasitology" at the department, attention is paid to the organization of extracurricular work of students, because the creditmodular (transfer) system of education involves a decrease in the amount of classroom work and increases the importance of student's independent work, allows to reveal one's individual abilities. The academic discipline provides for individual independent work of students, which can be in the form of speeches at a scientific student workshop, participation in scientific conferences, publication of reports in the form of abstracts and articles in scientific periodicals (journals, collections of scientific papers) and writing abstracts, and the like.

Teaching foreign students the section "Medical Parasitology" has its own characteristics, as it covers many issues of tropical parasitology, modern diagnostic methods and medical geography.

The assessment of the level of knowledge of foreign students in a practical lesson is carried out by the classical question-answer method, additional test tasks are used. Time is devoted to the study of macro- and micropreparations of parasites and sketches of their main morphological features in a workbook.

The teaching staff of the Department of Medical Biology and Genetics is constantly improving the teaching methods of the section "Medical Parasitology", using classical and newest methods (developments, approaches), thereby motivating the students of the HSEE of Ukraine "Bukovinian State Medical University" to active discussion work, participation in scientific workshop of the department and various conferences. The achievements of our students together with the teachers are presented at the Information stands of the department, which we are pretty proud of; this stimulates us to master the latest teaching and information presentation methods.

The latest teaching methods, such as the case method, gaming, smart technologies (using an interactive whiteboard), videos and the like, help students to consolidate the accumulated knowledge of the morphophysiological characteristics of protozoal parasites, helminths and arthropods, to show their importance in medicine, to understand, remember their taxonomy and biological features.

One of the most relevant is the case method, the method of specific situations. This is a method of active problemsituational analysis based on learning by solving specific problems - situations (developing cases). This method belongs to non-play simulation active teaching methods and is considered as a tool that allows one to apply theoretical knowledge in solving practical problems. It allows and assumes modeling of life situations, the use of role-playing games, joint problem solving based on an analysis of the circumstances of a clinical case.

Typically, the case includes the characteristics or symptoms of the disease / circumstances of infection / the results of laboratory tests or additional examination

ISSN 1727-4338 https://www.bsmu.edu.ua 
methods / photos, tables, diagrams. The final stage is a clear task (to determine a diagnosis, morphologically identify the pathogen, give recommendations for the prevention of further spread of the disease), which students must complete in a group discussion or individually.

Each case must correspond to the curriculum within which it is being solved, which contributes to the creation of purposeful and organized student work and the formation of appropriate professional skills. Such tasks motivate future doctors for research activities, analysis of information, form the ability to conduct a discussion, and develop communication skills. Group discussion teaches teamwork, the ability to make a collective decision.

There are a large number of parasites of humans and poisonous animals, the affect of which will require knowledge of the algorithms of medical care. Therefore, when teaching the section "Medical Parasitology" important aspects of knowledge are considered that will be needed by epidemiologists, infectious disease specialists, dermatologists, allergists, dentists and general practitioners in their professional activities.

The modern system of higher education needs the development of interdisciplinary ties, primarily natural sciences, as well as the development of innovative technologies in the training of future specialists [10, 12]. Optimization of the pedagogical process at the Department of Medical Biology and Genetics is carried out by improving the methods and means of teaching through the use of interactive forms of teaching, which is a necessary condition for ensuring the effectiveness of the learning process of students when studying the section "Medical Parasitology". This provides the prerequisites for the formation of professional thinking of students, contributes to their professional and personal development, stimulation of educational and cognitive activity, mastering the skills of a comprehensive analysis of situations, prompt decision-making, the ability to analyze additional information to clarify the initial situation, independence in decision-making, mastering practical experience etc.

The world in which a person lives becomes complex and contradictory. To develop a reasonable strategy for one's own life in it, it is necessary to have a sufficiently high intellectual and creative potential, a high competency, therefore one of the most important tasks of a higher school is the personal and professional growth of students. The society in which we live is developing and changing all the time. The modern world educational space is constantly being replenished with new content of knowledge, new qualification signs. New spheres of relations, new specialties are emerging, which form new disciplines. Higher school of Ukraine is in the process of reforming [11].

\section{Conclusion}

1. To optimize the educational process and highquality training of medical workers in the section "Medical Parasitology", it is necessary to use various teaching methods in combination with modern technologies, which contribute to better motivation of students for learning and ensure effective assimilation ISSN 1727-4338 https://www.bsmu.edu.ua of the material. 2. When studying medical parasitology, there is a need to use a large number of visual materials (multimedia presentations, tables, diagrams, illustrations, photographs, micro- and macro-preparations), which allow providing students with a large amount of information in the most convenient and accessible form. 3. Scientific and pedagogical personnel need to improve themselves constantly in accordance with the challenges of our time and modern learning conditions, including online learning.

\section{Список літератури}

1. Агаев ФТ, Мамедова ГА. Современные технологии электронного образования. Открытое образование. 2017;21(3):73-9. doi: https://doi.org/10.21686/1818-4243-20173-73-79

2. Бак М. Неперервність інформаційного супроводу освіти. Вища освіта України. 2014;3:50-7.

3. Викулина МА, Попова ЮА. Педагогические технологии в процессе формирования компетенций обучающихся в вузе. Современные проблемы науки и образования [Интернет]. 2015[цитировано 2020 Окт 12];6. Доступно: https://www. science-education.ru/ru/article/view?id=23036.

4. Жунисбекова ЖА, Абраманова НШ, Акимбаев АА, Керимбеков МА, Сыдыхов БД, Койшибаева НИ. Использование активных методов обучения в образовательном процессе вуза. Международный журнал экспериментального образования [Интернет]. 2015[цитировано 2020 Окт 10];3(Ч 3):279-82. Доступно: https://www.expeducation.ru/ru/article/ view?id=7110.

5. Іванова СВ. Інновації в освіті. Сучасні проблеми реформування системи вищої освіти в аспекті євроінтеграції України. Вісник Черкаського університету. Серія: Педагогічні науки. 2016;140:43-9.

6. Карпенко ОО, Каськова ЛФ, Хміль ОВ, Амосова ЛІ, Чуприна ЛФ, Маковка ІЛ. Стратегії та методи навчання в підготовці медичних кадрів. В: Матеріали Всеукр. навч.-наук. конф. 3 міжнар. участю Основні напрямки удосконалення підготовки медичних кадрів у сучасних умовах; 2015 Бер 26; Полтава. Полтава; 2015, с. 109-10.

7. Кремень ВГ, редактор. Національна доповідь про стан і перспективи розвитку освіти в Україні. Київ: Педагогічна думка; 2016. Розділ 10, Вища освіта України-трансформаційні процеси, стан і перспективи розвитку; с. 100-8.

8. Кучер ОН. Варианты включения дистанционных образовательных технологий, электронного обучения в учебный процесс вуза. Современные проблемы науки и образования [Интернет]. 2017[цитировано 2020 Окт 12];5. Доступно: https://www.science-education.ru/ru/article/ view?id=27008

9. Мальцева АН. Современные методы в учебном процессе медицинского вуза. Современные проблемы науки и образования [Интернет]. 2019[цитировано 2020 Окт 12]; 4. Доступно: https://www.science-education.ru/ru/article/ view?id=29040.

10. Филенко БМ, Ройко НВ, Пелипенко ЛБ, Ступанчук АП, Проскурня СА. Роль міждисциплінарних зв'язків та інноваційних технологій у підготовці студента-медика. В: Матеріали навч.-наук. конф. 3 міжнар. участю Інноваційні технології в організації самостійної роботи студентів медичних освітніх закладів; 2017 Бер 23; Полтава. Полтава; 2017, c. $173-4$

11. Шевченко В. Сучасні методи та технології навчання у вищій школі України. European Humanities Studiesn: Education and Клінічна та експериментальна патологія. 2020. Т.19, № 3 (73) 
Training. 2016;2:389-99.

12. Шестопалюк ОВ. Інноваційні моделі навчання в діяльності вищих навчальних закладів. Теорія і практика управління соціальними системами. 2013;3:118-24.

\section{References}

1. Agaev FT, Mamedova GA. Sovremennye tekhnologii elektronnogo obrazovaniya [Modern technologies of e-learning]. Otkrytoe obrazovanie. 2017;21(3):73-9. doi: https://doi. org/10.21686/1818-4243-2017-3-73-79 (in Russian).

2. Bak M. Neperervnist' informatsiinoho suprovodu osvity [Continuity of information support of education]. Vyscha osvita Ukrainy. 2014;3:50-7. (in Ukrainian).

3. Vikulina MA, Popova YuA. Pedagogicheskie tekhnologii v protsesse formirovaniya kompetentsiy obuchayushchikhsya $\mathrm{v}$ vuze [Pedagogical technologies in the process of forming the competencies of students at the university]. Sovremennye problemy nauki i obrazovaniya [Internet]. 2015[tsitirovano 2020 Okt 12];6. Dostupno: https://www.science-education.ru/ru/ article/view?id=23036 (in Russian).

4. Zhunisbekova ZhA, Abramanova NSh, Akimbaev AA Kerimbekov MA, Sydykhov BD, Koyshibaeva NI. Ispol'zovanie aktivnykh metodov obucheniya v obrazovatel'nom protsesse vuza [The use of active teaching methods in the educational process of the university]. Mezhdunarodnyy zhurnal eksperimental'nogo obrazovaniya [Internet]. 2015[tsitirovano 2020 Okt 10];3(Ch 3):279-82. Dostupno: https://www.expeducation.ru/ru/article/ view?id=7110 (in Russian).

5. Ivanova SV. Innovatsii v osviti. Suchasni problemy reformuvannia systemy vyschoi osvity $\mathrm{v}$ aspekti yevrointehratsii Ukrainy [Innovation in education. Current problems of higher education reform in Ukraine aspect integration]. Visnyk Cherkas'koho universytetu. Seriia: Pedahohichni nauky. 2016;140:43-9. (in Ukrainian).

6. Karpenko OO, Kas'kova LF, Khmil' OV, Amosova LI, Chupryna LF, Makovka IL. Stratehii ta metody navchannia v pidhotovtsi medychnykh kadriv [Strategies and methods of teaching in the training of medical personnel]. V: Materialy Vseukr. navch.-nauk. konf. z mizhnar. uchastiu Osnovni napriamky udoskonalennia pidhotovky medychnykh kadriv u suchasnykh umovakh; 2015 Ber 26; Poltava. Poltava; 2015, p. 109-10. (in Ukrainian).

7. Kremen' VH, redaktor. Natsional'na dopovid' pro stan i perspektyvy rozvytku osvity v Ukraini. Kiev: Pedahohichna dumka; 2016. Rozdil 10, Vyscha osvita Ukrainy - transformatsiini protsesy, stan i perspektyvy rozvytku [Higher education in Ukraine - transformation processes, state and prospects of development]; p. 100-8. (in Ukrainian).

8. Kucher ON. Varianty vklyucheniya distantsionnykh obrazovatel'nykh tekhnologiya, elektronnogo obucheniya $v$ uchebnyy protsess vuza [Options for the inclusion of distance educational technology, e-learning in the educational process of the university]. Sovremennye problemy nauki i obrazovaniya [Internet]. 2017[tsitirovano 2020 Okt 12];5. Dostupno: https:// www.science-education.ru/ru/article/view?id=27008 (in Russian).

9. Mal'tseva AN. Sovremennye metody v uchebnom protsesse meditsinskogo vuza [Modern methods in the educational process of a medical university]. Sovremennye problemy nauki i obrazovaniya [Internet]. 2019[tsitirovano 2020 Okt 12];4. Dostupno: https://www.science-education.ru/ru/article/ view?id=29040 (in Russian).

10. Fylenko BM, Roiko NV, Pelypenko LB, Stupanchuk AP, Proskurnia SA. Rol' mizhdystsyplinarnykh zv'iazkiv ta innovatsiinykh tekhnolohii u pidhotovtsi studenta-medyka [The role of interdisciplinary connections and innovative technologies in the training of medical students]. V: Materialy navch.-nauk. konf. z mizhnar. uchastiu Innovatsiini tekhnolohii v orhanizatsii samostiinoi roboty studentiv medychnykh osvitnikh zakladiv; 2017 Ber 23; Poltava. Poltava; 2017, p. 173-4. (in Ukrainian).

11. Shevchenko V. Suchasni metody ta tekhnolohii navchannia u vyschii shkoli Ukrainy [Modern methods and technologies of training in higher school in Ukraine]. European Humanities Studiesn: Education and Training. 2016;2:389-99. (in Ukrainian).

12. Shestopaliuk O. Innovatsiini modeli navchannia $v$ diial'nosti vyschykh navchal'nykh zakladiv [Innovative models of training in activity of higher educational establishments]. Teoriia $\mathrm{i}$ praktyka upravlinnia sotsial'nymy systemamy. 2013;3:118-24. (in Ukrainian).

\section{Відомості про авторів:}

Булик Р.С. - д.мед.н., професор, завідувач кафедри медичної біології та генетики Вищого державного навчального закладу України «Буковинський державний медичний університет», м. Чернівці, Україна.

Кривчанська М.І. - к.мед.н, доцент, доцент кафедри медичної біології та генетики Вищого державного навчального закладу України «Буковинський державний медичний університет», м. Чернівці, Україна.

Власова К.В. - к.мед.н., доцент кафедри медичної біології та генетики Вищого державного навчального закладу України «Буковинський державний медичний університет», м. Чернівці, Україна.

Йосипенко В.Р. - аспірант кафедри медичної біології та генетики Вищого державного навчального закладу України «Буковинський державний медичний університет», м. Чернівці, Україна.

Сметанюк О.В. - аспірант кафедри медичної біології та генетики Вищого державного навчального закладу України «Буковинський державний медичний університет», м. Чернівці, Україна.

\section{Сведения об авторах:}

Булык Р.Е. - д.мед.н., профессор, заведующий кафедрой медицинской биологии и генетики Высшего государственного учебного заведения Украины «Буковинский государственный медицинский университет», г. Черновцы, Украина.

Кривчанская М.И. - к.мед.н, доцент, доцент кафедры медицинской биологии и генетики Высшего государственного учебного заведения Украины «Буковинский государственный медицинский университет», г. Черновцы, Украина.

Власова К.В. - к.м.н., доцент кафедры медицинской биологии и генетики Высшего государственного учебного заведения Украины «Буковинский государственный медицинский университет», г. Черновцы, Украина.

Йосипенко В.Р. - аспирант кафедры медицинской биологии и генетики Высшего государственного учебного 
заведения Украины «Буковинский государственный медицинский университет», г. Черновцы, Украина.

Сметанюк А.В. - аспирант кафедры медицинской биологии и генетики Высшего государственного учебного заведения Украины «Буковинский государственный медицинский университет», г. Черновцы, Украина.

\section{Information about authors:}

Bulyk R.Ye. - Doctor of Medical Sciences, Professor, Head of the Department of Medical Biology and Genetics at Higher State Educational Establishment of Ukraine «Bukovinian State Medical University», Chernivtsi, Ukraine.

Kryvchanska M.I. - PhD, Associate Professor of the Department of Medical Biology and Genetics at Higher State Educational Establishment of Ukraine «Bukovinian State Medical University», Chernivtsi, Ukraine.

Vlasova K.V. - PhD, Associate Professor of the Department of Medical Biology and Genetics at Higher State Educational Establishment of Ukraine «Bukovinian State Medical University», Chernivtsi, Ukraine.

Yosypenko V.R. - Postgraduate student of the Department of Medical Biology and Genetics at Higher State Educational Establishment of Ukraine «Bukovinian State Medical University», Chernivtsi, Ukraine.

Smetaniuk O.V. - Postgraduate student of the Department of Medical Biology and Genetics at Higher State Educational Establishment of Ukraine «Bukovinian State Medical University», Chernivtsi, Ukraine.

Стаття надійшла до редакиії 13.08.2020

Рецензент - проф. Захарчук O.I.

(C) R.Ye. Bulyk, M.I. Kryvchanska, K.V. Vlasova, V.R. Yosypenko, O.V. Smetaniuk, 2020

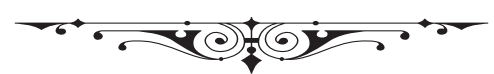

